\title{
WHAT IS THE LAW?
}

\author{
Lord Bingham*
}

This is the text of the 2008 Robin Cooke Lecture delivered by Lord Bingham on Thursday 4 December 2008.

It was very appropriate that the 1997 essays in honour of Lord Cooke of Thorndon should have been published under the title The Struggle for Simplicity in the Law. ${ }^{1}$ For, as Professor Sir David Williams pointed out in his contribution, a consistent theme of Lord Cooke's judicial and extrajudicial contributions to the law involved what he himself christened "the struggle for simplicity".2 This was not, as with a lesser man it might have been, a superficial slogan or catch-phrase. It touched on something which is, in the most literal sense, fundamental, as bearing on the rule of law itself.

I have described the core of the rule of law principle as being that all persons and authorities within the state, whether public or private, should be bound by and entitled to the benefit of laws publicly and prospectively promulgated and publicly administered in the courts. ${ }^{3}$ Observance of this principle requires that the law should be accessible and so far as possible intelligible, clear and predictable.

\section{WHY?}

I think that there are really three reasons. First, and most obviously, if you and I are liable to be prosecuted, fined and perhaps imprisoned for doing or failing to do something, we ought to be able without undue difficulty to find out what it is we must or must not do on pain of criminal penalty. This is not because bank robbers habitually consult their solicitors before robbing a branch of the

* Lord Bingham was Master of the Rolls from 1992 until being made Lord Chief Justice of England and Wales, and created a life peer as Baron Bingham of Cornhill, in 1996. In 2000 he became the first appointed Senior Lord of Appeal in Ordinary, before retiring in 2008.

1 Paul Rishworth (ed) The Struggle for Simplicity in the Law: Essays for Lord Cooke of Thorndon (Butterworths, Wellington) 1997.

2 Sir David Williams "Lord Cooke and Natural Justice" in Paul Rishworth (ed) The Struggle for Simplicity in the Llaw: Essays for Lord Cooke of Thorndon (Butterworths, Wellington, 1997) 177, 182; ibid, 192 footnote 19.

3 Lord Bingham "The Rule of Law" (2007) 66 CLJ 67, 69. 
local bank (they will know the law anyway), but because many crimes are a great deal less obvious than robbery, and most of us are keen to keep on the right side of the law if we can. One important function of the criminal law is to discourage criminal behaviour, and we cannot be discouraged if we do not know, and cannot reasonably easily discover, what it is we should not do.

The second reason is rather similar, but not tied to the criminal law. If the civil law gives us rights or imposes obligations on us which we or others can enforce, it is important to know what our rights or obligations are: otherwise we cannot claim the rights or perform the obligations. It is not much use being entitled to (say) an allowance from public funds if you cannot reasonably easily discover your entitlement, and how you set about claiming it. Equally, you can only perform a duty to (let us say) recycle different kinds of rubbish in different bags if you know what you are meant to do.

The third reason is rather less obvious, but extremely compelling. It is that the successful conduct of trade, investment and business generally is promoted by a body of accessible legal rules governing the rights and obligations of the parties. No one would choose to do business, perhaps involving large sums of money, in a country where the parties' rights and obligations were vague or undecided. This was a point recognised by Lord Mansfield around 250 years ago when he said: ${ }^{4}$

The daily negotiations and property of merchants ought not to depend upon subtleties and niceties; but upon rules easily learned and easily retained, because they are the dictates of common sense, drawn from the truth of the case.

In the same vein he said: ${ }^{5}$

In all mercantile transactions the great object should be certainty: and therefore, it is of more consequence that a rule should be certain, than whether the rule is established one way or the other. Because speculators [meaning investors and business men] then know what ground to go upon.

But this is not an old fashioned and outdated notion. Alan Greenspan, the former chairman of the Federal Reserve Bank of the United States, when recently asked, informally, what he considered the single most important contributor to economic growth, gave as his considered answer, "The rule of law". Even more recently, The Economist published an article which said: ${ }^{6}$

The rule of law is usually thought of as a political or legal matter ... But in the past ten years the rule of law has become important in economics too ... The rule of law is held to be not only good in itself,

4 Hamilton v Mendes (1761) 2 Burr 1198, 1214; 97 ER 787, 795.

$5 \quad$ Vallejo $v$ Wheeler (1774) 1 Cowp 143, 153; 98 ER 1012, 1017.

6 "Economics and the Rule of Law: Order in the Jungle" (13 March 2008) The Economist, cited by Tim Cowen, General Counsel and Commercial Director BT Global Services in "'Justice Delayed is Justice Denied': The Rule of Law, Economic Development and the Future of the European Community Courts", a paper prepared for the World Justice Forum on the Rule of Law held in Vienna 2 July 2008. 
because it embodies and encourages a just society, but also as a cause of other good things, notably growth.

Given the importance of this rule, we cannot be surprised to find it clearly stated by courts all over the world. In the House of Lords in 1975 Lord Diplock said: 7

The acceptance of the rule of law as a constitutional principle requires that a citizen, before committing himself to any course of action, should be able to know in advance what are the legal principles which flow from it.

He made much the same point a few years later: ${ }^{8}$

Elementary justice or, to use the concept often cited by the European Court [of the European Communities], the need for legal certainty demands that the rules by which the citizen is to be bound should be ascertainable by him (or, more realistically, by a competent lawyer advising him) by reference to identifiable sources that are publicly available.

The European Court of Human Rights at Strasbourg has spoken to similar effect: ${ }^{9}$

[T] he law must be adequately accessible: the citizen must be able to have an indication that is adequate in the circumstances of the legal rules applicable to a given case ... a norm cannot be regarded as a 'law' unless it is formulated with sufficient precision to enable the citizen to regulate his conduct: he must be able - if need be with appropriate advice - to foresee, to a degree that is reasonable in the circumstances, the consequences which a given action may entail.

So too the then Chief Justice of Australia in 2001, listing the practical conclusions held by Australian courts to be required by the principle of the rule of law: "... the content of the law should be accessible to the public." 10

Given the importance of this principle, it is, I think, desirable that States claiming allegiance to the rule of law should, from time to time, ask themselves how faithfully they observe this principle, how easy or difficult it is to discover with reasonable confidence what the law is.

7 Black-Clawson International Ltd v Papierwerke Waldhof-Aschaffenburg AG [1975] AC 591, 638 (HL).

8 Fothergill v Monarch Airlines Ltd [1981] AC 251, 279 (HL).

$9 \quad$ Sunday Times $v$ United Kingdom (1979) 2 EHRR 245, para 49.

10 Murray Gleeson "Courts and the Rule of Law" (Melbourne University, Melbourne, 2001). 
It must, first, be acknowledged that the problem is not a purely domestic one. It affects international law also. A committee of the American Bar Association recognised this half a century ago: ${ }^{11}$

The sources of international law are widely scattered. To get the law one must gather together and distill evidence accumulated from centuries of custom, international judicial and arbitral decisions, domestic decisions, writings of experts, publicists and diplomats, treaties, and many other sources. There is at the present time no adequate systematized compilation of the above. If we are ever to have a world rule of law it is obvious that there must be a current and complete set of source materials of international law which would include reports, digests, indices and commentaries. ... Previous attempts to create such practical tools in the international law field have met with only partial success.

Sir Hersch Lauterpacht was even blunter: ${ }^{12}$

[O]nce we approach at close quarters practically any branch of international law, we are driven, amidst some feeling of incredulity, to the conclusion that although there is as a rule a consensus of opinion on broad principle - even this may be an overestimate in some cases - there is no semblance of agreement in relation to specific rules and problems ... The fact, which is both disquieting and chastening, speaks for itself. There is, upon reflection, nothing astonishing about it. How could it be otherwise in a society in which judicial settlement is sporadic, in which there is no legislative activity in the accepted sense and in which custom is slow of growth and controversial in interpretation and application?

Nothing astonishing, perhaps, but disquieting certainly. For some issues of international law raise very big and fateful questions. It is, for example, remarkable and disturbing that there should be disagreement whether, consistently with the Charter of the United Nations, force may be used to avert an impending humanitarian catastrophe. These are not, however, the questions which most commentators have in mind when insisting that the law should be accessible, intelligible, clear and predictable.

In New Zealand, as in the United Kingdom, the primary source of law is statute. It is therefore of the first importance that statutes should be as clear and simple as the subject matter permits. I am in no way qualified to comment on the content or practice of legislation in New Zealand, and I will therefore adopt the role of tactful guest, declining to comment on the style of his host's furnishing. But perhaps a word about the British experience may be in order, if only as a cautionary tale.

11 ABA Special Committee on World Peace Through Law "The Rule of Law Among Nations: Background Information", 30 (1960), quoted by William J Bishop "The International Rule of Law" (1961) 59 Mich L Rev 553, 573 footnote 47.

12 H Lauterpacht"Codification and Development of International Law" (1955) 49 Am J Int'l L 16, 17 and 19, quoted Bishop, above n 11, 573 footnote 48. 
I do not question the technical virtuosity, erudition or professional skill of parliamentary draftsmen in the United Kingdom. But I do sometimes wonder whether more could not be done to ease the task of the unfamiliar reader. There are, I think, some fairly straightforward ways in which this could be done. One would be to include at the outset a statement of the objects which the statute is intended to achieve, or the principles on which it is based. These may be obvious. But if the court reaches the stage of purposive construction, it may be helpful to have a clear statement by the legislature of what the purpose is, however much detail there may be to follow. Another aid would, I think, be the use of bold type, italics or underlining to identify any term which is the subject of definition or explanation, with a footnote reference to where the definition or explanation is to be found, and such definition or explanation should be in that statute, not some other. A further aid would be to abandon the current practice of cross-reference. There may of course be occasions when it is useful or even necessary to adopt in a later statute a provision used in an earlier. But where this is done it should be repeated. This would inevitably lengthen the later statute, but it would obviate the need for a paper-chase through, sometimes, a series of earlier statutes. The same practice should be adopted in making amendments: if a later statute amends an earlier, it would be a powerful aid to comprehension if the provision, in its amended form, were spelled out in full. There is really no reason why the reader should have to tinker with the language of both statutes in order to see what the precise effect of the amendment is. Then of course there are the well-known virtues of brevity and plain language. I am sure I am preaching to the converted. In Australia, I understand, a taskforce appointed to simplify its Corporation Law cut one main section from 15,000 words to 2000, eliminated many unnecessary requirements, and redesigned and reorganised the entire text for easier access. ${ }^{13}$ In the United Kingdom, the Income Tax Act has been rewritten in plain language as a way to save administrative and compliance costs. ${ }^{14}$ But excessive brevity may bring its own problems. A Dutch statute governing general transport conditions provided that there should be no liability for damage to goods which were unwrapped or not sufficiently wrapped. The question then arose: what if the goods to be transported were of such a character that they could not be wrapped, such as a cow or (the example given in the commentary) an elephant? ${ }^{15}$ On this issue appellate courts in Amsterdam, Arnhem and The Hague reached a long stalemate, two favouring one view, one another. It would, one feels, have been easy to have provided that the carrier should be liable for no damage caused wholly or in part by lack or insufficiency of packing.

13 Ewoud Hondius "Sense and Nonsense in the Law" (Inaugural Address when accepting the Chair in European Private Law, University of Utrecht, Kluwer-Deventer, 28 November 2007) 23, citing Joseph Kimble "Answering the Critics of Plain Language" (1994-1995) 5 Scribes Journal of Legal Writing 51.

14 Hondius, ibid, 24 citing Kimble, ibid, 58.

15 Hondius, ibid, 14. 
The New Zealand Parliament has not, I understand, shown the same legislative hyperactivity as has characterised the Westminster Parliament in recent years. That is an achievement to be cherished. Again, I may perhaps speak briefly of the British experience, if only as a cautionary tale.

On 11 July 2007 Sir Menzies Campbell QC, then the Liberal Democrat leader, pointed out in the House of Commons that during the past ten years there had been 382 Acts of Parliament, including ten health Acts, 12 education Acts and 29 criminal justice Acts, and more than 3000 new criminal offences had been created. ${ }^{16}$ Professor Anthony King has drawn attention to a report published in 1992 which calculated that between 1979 and 1992 Parliament passed 143 Acts having a direct bearing on local government in England and Wales and that, of that total, no fewer than 53 effected some radical alteration to the existing system of local government. ${ }^{17}$ In the year 2006 nearly 5000 pages of primary legislation were enacted with, in addition some 11,500 pages of subordinate legislation. As Sir Menzies Campbell observed, "The mantra might have been 'Education, education, education' but the reality has been 'Legislation, legislation, legislation' ". 18

Professor Tony Smith has recently described the state of the English criminal law statute book as "little short of scandalous", referring to a perennial complaint by the editor of Archbold: ${ }^{19}$

In the latest (2008) edition, he notes that on 8 November 2006, Parliament enacted (but did not necessarily bring in to force) mainstream criminal legislation that included the Violent Crime Reduction Act 2006, the Fraud Act 2006, the Police and Justice Act 2006, the Road Safety Act 2006 and the Safeguarding Vulnerable Groups Act 2006. As the editor put it:

"In the main, these consisted of the usual hotch-potch of amendments to earlier legislation. The Road Safety Act, in particular, comprises nothing other than amendments of bewildering detail, compounded in some cases by the technique of double amendment, i.e. providing for one set of amendments to come in to force on a day to be appointed (none as yet appointed as at mid-October 2007) and then providing for amendments to the amendments to come into force as from a later day. With the best will in the world, it must be almost impossible for the most conscientious practitioner to keep abreast of the current state of the law."

Professor Smith observes: "In short, it is often extremely difficult to produce a clear and uncorrupted text of what Parliament has said even before the task of interpretation begins". ${ }^{20}$

16 (11 July 2007) 462 GBPD ser 6, col 1455.

17 Anthony King The British Constitution (Oxford University Press, Oxford, 2007) 176, referring to Hansard Society Commission Making the Law: The Report of the Hansard Society Commission on the Legislative Process (Hansard Society, London, 1992) 19, 291.

18 Above n 16.

19 Tony Smith "The Interpretation of Criminal Statutes" in Jeremy Finn and Stephen Todd (eds) Law, Liberty, Legislation: essays in honour of John Burrows QC (LexisNexis, Wellington, 2008) 34-35. 
It is, indeed, extremely difficult, not only for the practitioner but for the judge also. Such changes lead to a proliferation of appeals, and the Criminal Cases Review Commission, established to refer suspected miscarriages of justice back to the Court of Appeal, has described the complexity of recent sentencing provisions as a continuing source of references. ${ }^{21}$

It might be thought that with the aid of the internet and electronic databases problems of this kind could be overcome. But a case very recently reported highlights both the gravity and the prevalence of the problem. ${ }^{22}$ The case concerned a confiscation order made against a defendant convicted of smuggling. It so happened that the day before a Court of Appeal of three judges was due to give judgment upholding the order that he pay $£ 66,120$, the judges accidentally discovered that the regulation at the heart of the legal argument had been repealed seven years ago, a fact of which neither the original judge, nor counsel in the case, nor the appellate judges were aware. Enquiries revealed that other court rulings had very probably been based on the defunct regulation. The presiding Lord Justice deplored the existing state of affairs: ${ }^{23}$

It is profoundly unsatisfactory if the law itself is not practically accessible ... even to the courts whose constitutional duty it is to interpret and enforce it ... there is no comprehensive statute law database with hyperlinks which would enable an intelligent person, by using a search engine, to find out all the legislation on a particular topic.

The situation was lamentable (he added) because it affected many areas of law with direct impact on the ordinary citizen, including sensitive childcare issues and social security benefits. A newspaper reporter concluded by suggesting that the age-old maxim might have to be revised: ignorance of the law is no excuse, unless there is no way of finding out what the law is. This was no doubt intended as a jest. But the Italian Constitutional Court has twice held, in 1988 and 1995, that ignorance of the law may constitute an excuse for a citizen when the formulation of the law is such as to lead to obscure and contradictory results. ${ }^{24}$

Judges are usually quite ready to criticise the obscurity and complexity of legislation. But those who live in glass-houses are ill-advised to throw stones. The length, elaboration and prolixity of some common law judgments (in the United Kingdom, the United States, Australia, Canada and perhaps even New Zealand) can in themselves have the effect of making the law to some extent inaccessible.

20 Ibid, 35.

21 Criminal Cases Review Commission, Annual Report and Accounts, 2007/2008, 16.

$22 R v$ Chambers [2008] EWCA Crim 2467. See also Marcel Berlins "A Kafkaesque excuse for ignorance of the law" (3 November 2008) The Guardian 12.

$23 R v$ Chambers, above $\mathrm{n} 22$, paras $64-68$.

24 Hondius, above n 13, 32. 
I hope I may be permitted another, rather extended, cautionary tale. I was myself party to two of the relevant appeals in the House of Lords, and was in the minority each time. So the grape harvest was sour to me. But my purpose is not to criticise the outcome, but to question whether decisionmaking in this fashion best serves the needs of the community. The question was whether, when a local authority seeks possession of premises which a person has occupied as his home, but which under the law applicable to tenancies and caravan sites he has no right to continue to occupy (because his tenancy has expired or he has been given notice to quit), he can seek to resist eviction by relying on the right to respect for his home protected by article 8 of the European Convention on Human Rights, given effect in the UK by the Human Rights Act 1998. The detached observer might suppose that the answer to the question might be "yes" or "no" or "sometimes", and if "sometimes" would expect clear guidance to be given on when article 8 could be relied on and when it could not. He would be doomed to disappointment.

The first case concerned a man (Mr Qazi) who had, with his wife, been a joint tenant of a house let to them by the Harrow Borough Council, a public housing authority. ${ }^{25}$ The wife left, and gave notice to quit to the housing authority, bringing the tenancy to an end. Mr Qazi applied for a new sole tenancy, but was refused. He did not leave as requested, and the authority applied to the court for a possession order, which he resisted in reliance on his article 8 right. The judge made the order, holding that once the notice to quit had expired the house was no longer Mr Qazi's home. The Court of Appeal disagreed, and remitted the case so that justification could be considered. The housing authority then appealed to the House of Lords which held, unanimously, that the house was $\mathrm{Mr}$ Qazi's home. But by a majority of 3-2 it held that article 8 could not be relied on to defeat the local authority's claim to possession. The minority did not hold that Mr Qazi's article 8 right should prevail, only that he had such a right which might, depending on the facts, call for consideration.

The next step in the saga was a decision of the European Court of Human Rights. ${ }^{26}$ The decision was given on 10 June 2004, nearly a year after Mr Qazi's case, and concerned a gipsy named Mr Connors. He had been evicted by Leeds City Council from a gipsy site which he and his family had occupied as their home. He had failed in the courts and applied to Strasbourg. It was agreed between the parties (one of which was the UK) that article 8 was applicable, that there had been an interference with Mr Connors' article 8 right, and that the council's action had been in accordance with the law. The crucial issue was whether the council's action had been "necessary in a democratic society", or proportionate. Finding in favour of Mr Connors, the Strasbourg court found that the eviction of himself and his family had not been attended by the requisite procedural

25 Harrow London Borough Council v Qazi [2004] 1 AC 983 (HL).

26 Connors v United Kingdom [2004] 40 EHRR 189. 
safeguards, namely the requirement to establish proper justification for the serious interference with his rights, and so could not be regarded as justified by a "pressing social need" or as proportionate. ${ }^{27}$

The first domestic court to consider the effect of Connors was the Court of Appeal in Kay and others $v$ Lambeth Borough Council and another ${ }^{28}$ On the facts of the case the Court held, rightly, that the appellants had no contractual or proprietary right to remain in the premises they had previously occupied, but dismissed the Strasbourg decision in Connors (not fully reported at the time) as "only of assistance to the courts of this country in relation to cases involving gipsies". ${ }^{29}$

The next case to come before the Court of Appeal, a few months later, was Leeds City Council v Price and others. ${ }^{30}$ The appellants in that case were gipsies, or in any event travellers, and had little in the way of merit, having moved without permission on to recreational land owned by the council, from which the council understandably sought to remove them. The only question was whether the appellants could, in principle, rely on article 8. The majority decision in Qazi was plain authority that they could not. But in a judgment of the court delivered by the Master of the Rolls, Lord Phillips of Worth Matravers, it was held that the decision in Connors' case was unquestionably incompatible with the proposition that the exercise by a public authority of an unqualified proprietary right under domestic law to repossess its land would never constitute an interference with the occupier's right to respect for his home, or would always be justified under the exceptions in article 8(2). To that extent, it was held, Connors' case was incompatible with Qazi's. ${ }^{31}$ The Court did not agree with the Court of Appeal's reasoning in Kay that Connors only applied to gipsies. ${ }^{32}$ Addressing the question whether it should follow the Lords' decision in Qazi or the Strasbourg decision in Connors, it concluded that it was bound to follow Qazi. It accordingly dismissed the appeal, but gave the appellants leave to appeal. ${ }^{33}$

The appeals in Kay and Price reached the House of Lords together. Since two Courts of Appeal differed in their reading of Connors, and one considered the majority decision of the house in Qazi to be plainly irreconcilable with Connors, a seven-member constitution was mounted to hear them. In both cases the landlord's claim for possession in domestic law was clear. But on the article 8 issue, the House this time divided 4-3. The majority held that where the requirements of domestic law had been satisfied and the right to recover possession was unqualified, no challenge based only

27 Ibid, para 95.

28 Kay v Lambeth Borough Council [2005] QB 352 (HL).

29 Ibid, para 106.

30 Leeds City Council v Price and others [2005] 1 WLR 1825 (HL).

31 Ibid, para 25.

32 Ibid, para 30.

33 Ibid, para 33. 
on a defendant's individual circumstances could avail him under article 8 . The minority, fortified by Connors, did not accept this view.

That was not the end of the matter. In Doherty v Birmingham City Council (Secretary of State Intervening $)^{34} \mathrm{Mr}$ Doherty and his family, who were gipsies, had occupied a council-owned caravan site for 17 years under a licence granted by the council until they were given notice to quit. The council wanted to carry out work to improve the site. The judge, following Qazi, gave judgment in favour of the council, but he later gave leave to appeal and certified the case as suitable for an appeal direct to the House. An appeal committee of the House, however, considered that the forthcoming appeals in Kay and Price (which had yet to be heard) would provide all necessary guidance and refused leave for a direct appeal. So Mr Doherty appealed to the Court of Appeal which, seeking to apply the ruling of the House in Kay and Price, dismissed his appeal. So he then appealed to the House. In the House, as in the Court of Appeal, much argument centred on the meaning and application of one paragraph in one of the majority opinions in Kay and Price. But the House held that the Court of Appeal had misunderstood and misapplied that paragraph. So the case was remitted to the High Court for it to consider the reasonableness of the local authority's decision to serve notice to quit. After argument, but before delivery of judgment, the Strasbourg court had delivered a further judgment, apparently favourable to Mr Doherty. ${ }^{35}$

In the result, the House of Lords has heard three appeals on this point within five years, and the question at issue has been addressed in 15 separate reasoned judgments running to over 500 paragraphs and over 180 pages of printed law report. Even after this immense outpouring of effort, it must be doubted whether the relevant law is entirely clear, or for that matter finally settled. This cannot be regarded as a satisfactory discharge of the judges' duty to make the law accessible, intelligible, clear and predictable.

The experience of grappling with the problem of interpreting and applying the majority decision in Kay and Price (in the event, as was to be held, unsuccessfully) prompted the Court of Appeal to take an unusual course. It drafted, but did not include in its judgment as delivered, a passage which looked forward to the establishment of a Supreme Court of the United Kingdom and made a heartfelt plea. The passage has since achieved some currency, and reads: ${ }^{36}$

66. A single majority opinion could have been very helpful in a case like the present, where what is needed is straightforward guidance for a commonplace situation in the ordinary courts. No doubt the exchange of detailed draft speeches was an important part of the internal debate within the House. But it would have been helpful for there to have been a more readily digestible final product. Furthermore, in

35 McCann v United Kingdom [2008] LGR 474 (ECHR).

36 Text seen by author, with original paragraph numbers. 
the process, sight seems to have been lost of the original objective of the whole exercise: that is, the need for definitive guidance as to how to accommodate Connors and cases like it into domestic law (not simply the two cases before them). The analysis which we have attempted may be right or wrong. But in a properly staffed Supreme Court, a similar task could perhaps have been undertaken by an experienced legal officer, supervised by a reporting judge. The areas of uncertainty could have been identified. They could have been clarified or resolved by discussion with the writers, instead of by comparative textual analysis. The result might have been an agreed summary, in a form similar to that which we have attempted, but with the advantage of authority.

67. As it is we cannot avoid the risk that the council and the Doherty family will be involved in another trip to the House of Lords, and possibly to Strasbourg, before they finally know their respective rights, and (if our decision is upheld) the council's plans for the site may perhaps be able to proceed.

Since judicial judgments occupy a central place in a precedent-based common law system such as prevails in New Zealand and the UK, and judges have a clear duty to try and make the law accessible, it is, I think, incumbent on us to pose and seek to answer some rather basic questions. Lord Cooke would, I think, have said "Amen" to that, whether or not he would have approved of my answers.

\section{A Who is the Judge Addressing When Giving Judgment?}

The first answer is, of course, the parties and their advisers, who must be told who has won and why, and what (if any) relief is to be given. In many unreserved first instance judgments, particularly those turning on the facts, this will be the only audience. But most reserved judgments on questions of law, notably appellate judgments, address an audience beyond the immediate parties and their advisers. It is appellate judgments with which I am now concerned. The appellate judges' wider audience will probably include those members of the legal profession who may be asked to advise on the point at issue and courts who have to apply the law laid down. It will often include law teachers who have responsibility to summarise and discuss the law in lectures, books or articles. It will often, depending on the subject matter, address non-legal professionals, such as administrators, doctors, social workers, auctioneers, insurance brokers, bankers, shipowners, and so on. In a case which has attracted the interest of the media, the audience is likely to include the general public.

Special considerations apply to a dissenting judgment. The tradition of continental Europe is, of course, that the court should speak with a single authoritative voice, but most common law judges would not readily forgo the right to dissent from a majority decision which they consider to be unsound, unjust or potentially mischievous. In dissenting, the judge is, I think, addressing the judges of successor courts, since it is well known that the dissent of today may become the orthodoxy of tomorrow. Lord Atkin's dissent in Liversidge $v$ Anderson ${ }^{37}$ is perhaps the most famous British

37 Liversidge v Anderson [1942] AC 206, 225-247 (HL). 
example, but the dissent of Lord Scarman and Lord Brightman in Riley $v$ Attorney-General of Jamaica, ${ }^{38}$ vindicated in Pratt $v$ Attorney-General for Jamaica, ${ }^{39}$ is scarcely less worthy of celebration. As Lord Steyn (dissenting) observed in Fisher $v$ Minister of Public Safety and Immigration: 40

A dissenting judgment anchored in the circumstances of today sometimes appeals to the judges of tomorrow. In that way a dissenting judgment sometimes contributes to the continuing development of the law.

A well-argued and persuasive dissent may also prove a potent stimulus to statutory intervention, as did Lord Rodger's recent dissent in Barker v Corus UK Ltd ${ }^{41}$ and as will, I hope, Baroness Hale's dissent (supported by me) in YL $v$ Birmingham City Council and others (Secretary of State for Constitutional Affairs intervening). ${ }^{42}$

\section{B Are there any Essential Ingredients of a Judgment or (in an Appellate Court) Group of Judgments?}

Judgment-writing is an art, and (in the common law world) a highly individual art, so one must beware of overly prescriptive rules. But I think there are certain ingredients which a good judgment should contain. First, it is generally helpful to identify at the outset, very succinctly, the central point in the case. The reader then knows, reading through the (maybe lengthy) text, what to look for. It sets the compass. There must, at some point, be a summary of the salient facts. Unnecessary detail is to be avoided, a point characteristically made by Lord Diplock on an early appeal from myself when he said: ${ }^{43}$

[T] he essential facts can be stated in summary form as follows, leaving the curious reader to expand the summary if he so wishes by reference to the judgment of Bingham $\mathrm{J}$.

Some account of the history of the litigation is usually called for, and a summary of the parties' respective contentions, although there is in my opinion a tendency to rehearse these at quite unnecessary length. It is a common complaint of judges from whom appeals lie, at least in England, that appellate courts pay scant regard to their carefully-considered judgments, and I think this is often a justified complaint. Courtesy alone demands that some attention be paid to the judge's

38 Riley v Attorney-General of Jamaica [1983] 1 AC 719, 727-736 (PC).

39 Pratt v Attorney-General for Jamaica [1994] 2 AC 1 (PC).

40 Fisher v Minister of Public Safety and Immigration [1998] AC 673, 686.

41 Barker v Corus UK Ltd [2006] 2 AC 573, para 66-102 (HL).

$42 Y L v$ Birmingham City Council and others (Secretary of State for Constitutional Affairs intervening) [2007] 3 WLR 112, para 36-75 (HL).

43 Cheall v Association of Professional Executive Clerical and Computer Staff [1983] 2 AC 180, 186 (HL). 
reasons for his or her decision, which is in any event usually necessary to explain an appellate judge's reasons for agreeing or disagreeing. Then come the reasons of the appellate judge for allowing or dismissing the appeal, the all-important ratio. If there is not a clearly stated ratio to which at least a majority of an appellate court subscribes, that court is, in my opinion, manifestly failing to perform one of the important functions for which it exists.

\section{Are there any Qualities which a Good Judgment Should Have?}

Yes, there are. The object of a judgment is to communicate. Ideally, therefore, it will have all the qualities which make for effective communication: simplicity, brevity and clarity.

To Einstein is attributed the aphorism: "Everything should be made as simple as possible, but not simpler". ${ }^{44}$ This seems to me to express a profound truth. There are some subject matters which cannot, without distortion or caricature, be made entirely simple. But simplicity should, as Lord Cooke recognised, be a constant aim, well worth a struggle. On the whole, I think that the most distinguished and influential judgments tend to leave the law simpler than it was before, not less so. There is truth in the aphorism of E F Schumacher that "Any intelligent fool can invent further complications, but it takes a genius to attain, or recapture, simplicity".

Brevity is, I think, an underrated virtue in judgments, which have in most common law jurisdictions have become much longer than they were. Why is this? No doubt the seductive embrace of the word-processor and the dictating machine has something to do with it, since anything written out by hand tends to be more sparingly composed. These methods of composition also facilitate the reproduction of large chunks of quotation, much of it scarcely relevant, and spare the author the undoubted labour of giving a summary which is both brief and completely accurate. But long passages of single-spaced quotation tempt all but the most scholarly reader to fast-forward to the next passage of reader-friendly text, weakening the thrust of the judgment. It may be that in some jurisdictions the advent of law clerks or judicial assistants has contributed to the length of judgments, since how can a judge be so ungrateful as to ignore all the research material that his able young assistant has harvested? But perhaps the main reason why judgments have become longer and more prolix is to be found in a judicial desire, in an age which demands ever more transparency and accountability, to be seen to be doing a good professional job. So the t's must be crossed and the i's dotted, to avert the complaint or criticism that this or that point has been ignored or left unanswered. This is no doubt a laudable motive, but there comes a point at which assiduity becomes a vice.

And, lastly, clarity. This is no doubt a feature of all good writing, but it is a particularly important feature of legal writing since, as is well known to us all, a loose or ambiguous expression can be a potent source of mischief. So the challenge is, I think to write good, accurate English, perhaps slightly formal as befits a judgment, avoiding on the one hand a style that is stilted,

44 See Mark Adler Clarity for Lawyers (2 ed, The Law Society, London, 2006) 32. 
pompous, portentous or archaic and on the other one that attempts to be racy or resorts to slang or is populist in tone.

In commending the virtues of simplicity, brevity and clarity I am vividly conscious, as this audience will be, that Lord Cooke's judgments were shining examples of all three. There could be no better illustration than his lapidary statement of the grounds for judicial review, quoted by Professor Philip Joseph in his admirable work on Constitutional and Administrative Law in New Zealand: "[T]he decision-maker must act in accordance with law, fairly and reasonably". ${ }^{45}$ It would be impossible to state this proposition more simply, more briefly or more clearly, and if today we would include to add "proportionately", that would only increase the 11 words to 12 .

I turn to my fourth question.

\section{Are Multiple Judgments in Appellate Courts Always Desirable?}

The Court of Appeal in Doherty thought not, and questioned the applicability, today, of the preference for multiple judgments expressed by Lord Reid in $1971 .{ }^{46}$ He considered that the quality of single Privy Council judgments had on the whole been inferior from the point of view of developing the law to the more diverse opinions of the House of Lords. I share his view. Provided always that there is a clear majority ratio, different minds approaching the same problem from different angles, reflecting different professional and (in the UK) jurisdictional backgrounds, can illuminate different facets of the problem in a way which a single judgment would not. In any event, the premise of my question, which I think Lord Cooke would on the whole have shared, is that multiple judgments are generally desirable.

There are, however, certain categories of case in which I think a single judgment of the court is desirable as best serving the rule of law. The first category I would identify is judgments on questions of professional conduct and responsibility. The need here is for a clearly defined rule which practitioners and judges can readily absorb and apply. Thus, in a case dealing with the personal liability of legal practitioners to pay costs unnecessarily incurred in the conduct of litigation, ${ }^{47}$ and again in a case dealing with bias and the appearance of bias in judges, ${ }^{48}$ the Court of Appeal decided to deliver a single judgment. Different sections of the judgments were drafted by

45 Philip A Joseph Constitutional and Administrative Law in New Zealand (3 ed, Brookers, Wellington, 2007) 871: see Sir Robin Cooke "Third Thoughts on administrative law" [1979] NZ Recent Law 218, 225; "The Struggle for simplicity in administrative law" in M Taggart (ed) Judicial Review of Administrative Action in the 1980s (Oxford University Press, Auckland, 1986) 2; NZ Fishing Industry Assn Inc v Minister of Agriculture and Fisheries [1988] 1 NZLR 544, 552.

46 "The Judge as Law-Maker" (1972) 12 Journal of Public Teachers of Law (NS) 22, 28-29.

47 Ridehalgh $v$ Horsefield [1994] Ch 205 (CA).

48 Locabail (UK) Ltd v Bayfield Properties Ltd [2000] QB 451 (CA). See also Lawal v Northern Spirit Ltd [2003] ICR 856 where the same practice was followed in the House of Lords. 
different members of the court, but the judgments were delivered as a single authoritative statement by the court.

A second category of case in which, I think, a single judgment is generally desirable is in cases pertaining to crime, particularly criminal practice. The doubts and nuances and differences of emphasis which may properly feature in individual judgments can only embarrass a police officer who needs to know what he or she should do in conducting a difficult investigation, or a judge conducting a criminal trial, called upon to give a ruling at short notice with little time for reflection, or required to direct a jury in terms which even the less sophisticated members can understand. In the Criminal Division of the English Court of Appeal a single judgment has always been the invariable practice, but in the House of Lords the practice is of more recent vintage. It has in recent years been followed in cases concerning the conduct of identification parades, ${ }^{49}$ criminal culpability, ${ }^{50}$ the proceeds of crime, ${ }^{51}$ the prosecution duty of disclosure, ${ }^{52}$ directions to a jury to convict, ${ }^{53}$ the questioning of suspects by the police, ${ }^{54}$ the offence of administering noxious drugs, ${ }^{55}$ dishonest price-fixing, ${ }^{56}$ criminal confiscation orders ${ }^{57}$ and the past criminality of anti-competitive behaviour. ${ }^{58}$ A similar approach has been taken to the conduct of inquests. ${ }^{59}$ In cases such as these the public interest is not, in my opinion, advanced by promulgation of a variety of viewpoints.

My third category is much smaller, and also harder to identify. Cases do, however, arise in which an appellate court feels that the arguments addressed by counsel in the lower courts, and the judgments of the lower courts in response to those arguments, have led to undue complication, overelaboration and mystification of an area of the law which could and should be stated much more

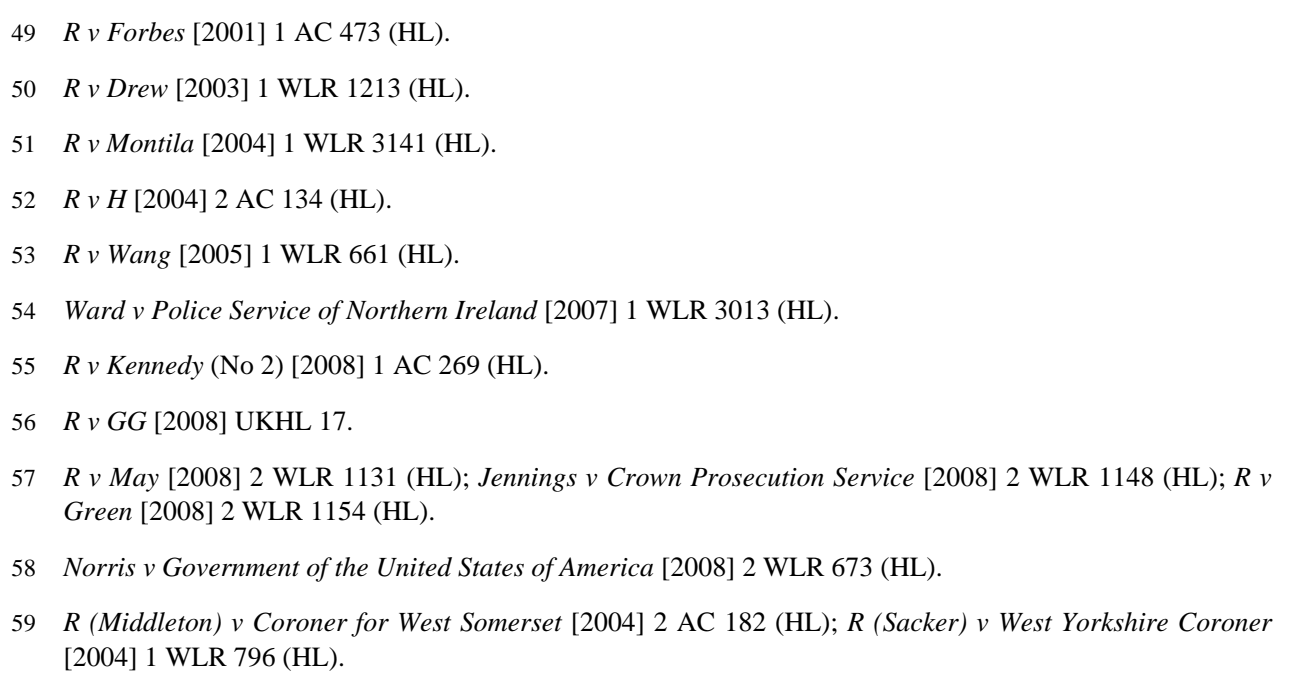


simply. ${ }^{60}$ In such a situation, there is value in a single lapidary and authoritative statement setting out the law shorn of all superfluous excrescences.

Before leaving this topic, perhaps I may ventilate a personal preference. Where, in an appellate court, one judge gives a judgment to which the others agree without qualification, addition or reservation, it seems to me much better that the judgment be that of the court delivered by the member whose judgment it is. The difference may be largely cosmetic, but it seems to me preferable that such a judgment should be presented as that of the court rather than of a single member.

One final point and I am done. Lord Cooke always, I think, rejected the description "activist", and rightly so. For it is plain that an undue willingness in a judge to innovate subverts the very principle I am commending. Particularly is this so in the criminal field, and I note that Professor Tony Smith has praised the New Zealand judges, blessed with a criminal code, for their faithful interpretation of it in accordance with the intention of Parliament, comparing them favourably with their English counterparts. ${ }^{61}$ It is one thing to apply existing principles to a new situation, or fill a gap, or move one step forward when an existing train of authority peters out, or nudge the law in the direction of modernity. These are things which a legal adviser can reasonably be expected to foresee and allow for. It is quite another to strike out in new and unpredictable directions. This was not Lord Cooke's style. It was for his great gifts as a simplifier, a clarifier, an expounder of the law that he is remembered with such admiration and respect.

60 This was the view of the House of Lords in Huang v Secretary of State for the Home Department [2007] 2 AC 167 (HL).

61 Smith, above n 19, 36-41. 